\title{
Феликс Яковлевич Кон: хронология Засаянской экспедиции
}

\author{
Галина Д. Неганова, Нина С. Ганцовская
}

Костромской государственный университет, Российская Федерация

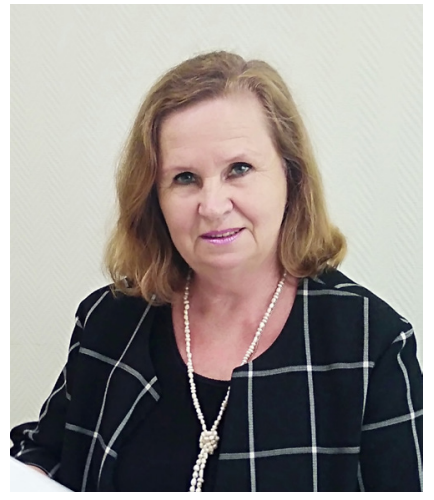

2019 год насыщен памятными датами, связанными с жизнью и научной деятельностью Ф. Я. Кона, исследователя истории и культуры тувинского и других народов Восточной и Южной Сибири. В числе этих юбилейных дат - 85-летие выхода его собрания сочинений «За пятьдесят лет» (1934), третий том которого составляет «Экспедиция в Сойотию». Книга была написана по материалам Засаянской экспедиции (в Туве), которая проводилась по поручению Восточно-Сибирского отдела Императорского Русского географического общества (ВСОИРГО). Исследователи неизменно высоко оценивают результаты экспедиции Ф. Я. Кона, не уделяя при этом особого внимания ее хронологии.

Ее хронология восстанавливается по материалам протоколов заседаний и отчетов ВСОИРГО, а также писем и отчетов Ф. Я. Кона. Подготовительный этап экспедиции, начавшийся весной 1901 г., затянулся до следующего года. Разработанная в этот период программа экспедиции была опубликована лишь в начале 1904 г. Второй этап экспедиции продолжался в течение двух лет. Последовательность событий 1903 2. вы-

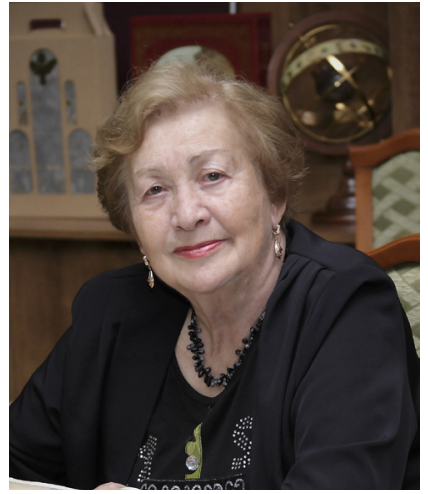
страивается по периодам в соответствии с маршрутами второго года экспедиции, начавшейся 27 марта и завершившейся 4 августа, и фазами стационарной работы.

Хронологические рамки первого этапа исследования разнятся в рассмотренных источниках. Также, помимо представленного Ф. Я. Коном взгляда на решение вопроса, вынудившего его прервать экспедицию в марте 1902 г., показаны действия, предпринятые Распорядительным комитетом ВСОИРГО. Уточняется дата фактической публикации информации об экспедиции Ф. Я. Кона в Русском антропологическом журнале. Хронология экспедищии позволяет уточнить ход проведенных Ф. Я. Коном экспедиционных исследований. Собранные им материалы в основном этнографического характера. Вместе с тем они представляют несомненную ценность для лингвистов, в первую очередь топонимистов и диалектологов. Авторы статьи полагают, что в дневнике Засаянской экспедиции обнаружатся лексические материалы, которые в перспективе станут предметом научного исследования.

Ключевые слова: Феликс Яковлевич Кон; Тува; Сойотия; история Тувы; исследователь Тувы; Экспедиция в Сойотию

\section{Для цитирования:}

Неганова Г. Д., Ганцовская Н. С. Феликс Яковлевич Кон: хронология Засаянской экспедиции [Электронный ресурс] // Новые исследования Тувы. 2019, № 4. URL: https://nit.tuva.asia/nit/article/view/984 (дата обращения: дд.мм.гг.). DOI: 10.25178/nit.2019.4.18

Неганова Галина Дмитриевна - кандидат культурологии, старший научный сотрудник учебно-научной исследовательской лаборатории «Лексикология и лексикография» Костромского государственного университета. Адрес: 160005, Россия, г. Кострома, ул. Дзержинского, д. 17. Тел.: +7 (4942) 39-16-27. Эл. адрес: cultland@yandex.ru ORCID ID: 0000-0003-3247-1440

Ганциовская Нина Семёновна - доктор филологических наук, профессор кафедры отечественной филологии Костромского государственного университета. Адрес: 160005, Россия, г. Кострома, ул. Дзержинского, д. 17. Тел.: +7 (4942) 39-16-34. Эл. адрес: gantsovsky_n@mail.ru ORCID ID:0000-0002-2896-064X

Neganova Galina Dmitrievna, Candidate of Cultural Studies, Senior Researcher, Educational and Scientific Research Laboratory "Lexicology and Lexicography", Kostroma State University. Postal address: 17 Dzerzhinsky St., Kostroma, 160005, Russia. Tel.: +7 (4942) 39-16-27.E-mail: cultland@yandex.ru

Gantsovskaya Nina Semenovna, Doctor of Philology, Professor, Department of Russian Philology, Kostroma State University. Postal address: 17 Dzerzhinsky St., Kostroma, 160005, Russia. Tel.: +7 (4942) 39-16-34.E-mail: gantsovsky_n@mail.ru 


\title{
Feliks Yakovlevich Kon: chronology of the expedition beyond the Sayan mountains
}

\author{
Galina D. Neganova, Nina S. Gantsovskaya \\ Kostroma State University, Russian Federation
}

\begin{abstract}
The year 2019 is rich in memorial dates linked to the life and research of Feliks Yakovlevich Kon, a scholar of the history and culture of Tuvans and other peoples. The list of these dates includes 85th anniversary of the publication of his collected works under the title "Za pyatdesyat let" (In fifty years", 1934). The third volume of this collection contains his "Expedition to Soyotia". The book was written on the basis of the materials collected during the Trans-Sayan expedition (to Tuva), which was organized at the behest of the East Siberian Department of the Imperial Russian Geographical Society (ESDIRGS). Researchers have been highly appreciative of the expedition's outcomes, but little attention has so far been paid to the chronology of the events in the F. Ya. Kon-led expedition.

We have reconstructed the order of events from the proceedings and reports drafted by the ESDIRGS, as well as from Kon's own reports and correspondence. Preparation for the expedition began in spring 1901 and continued until next year. The action plan drafted at this stage was not published until early 1904. The second stage of the expedition took 2 years to complete. The chronology of events in the year 1903 have been reconstructed and classified into periods in accordance with the routes the expedition followed in its second year, between March 27 and August 4, as well as from the phases of stationary work.

Our sources do not agree about the time limits of the expedition's first year. In addition to Kon's view of the events and his decision to suspend the expedition in March 1902, we also focus on the measures taken by the Steering Committee of the ESDIRGS. The date when the information on Kon's expedition was actually published in the Russian Anthropological Journal, has also been clarified.

The study of the expedition's chronology helps get a better grasp of the course of studies followed by Kon in his expedition. Its materials being largely of an ethnographic character, they nevertheless are of unique value for linguists, especially those specializing in toponyms and dialects. We believe that the diary of the Trans-Sayan expedition contains important lexicological materials which deserve a dedicated study.
\end{abstract}

Keywords: Feliks Yakovlevich Kon; Tuva; Soyotia; history of Tuva; scholar of Tuva; "An Expedition to Soyotia”

\section{For citation:}

Neganova G. D. and Gantsovskaya N. S. Feliks Yakovlevich Kon: chronology of the expedition beyond the Sayan mountains. The New Research of Tuva, 2019, no. 4. URL: https://nit.tuva.asia/nit/article/view/984 (дата обращения: дд.мм.гг.). DOI: 10.25178/nit.2019.4.18

\section{Введение}

2019 год - юбилейный для памятных дат и фактов жизни Феликса Яковлевича Кона (1864-1941), исследователя истории и культуры тувинского и других народов Восточной и Южной Сибири: 155-летие со дня рождения (18/30 мая 1864 г., Варшава); 125-летие Сибиряковской экспедиции (этнографической экспедиции И. М. Сибирякова), в которой участвовал Феликс Яковлевич; 85-летие выхода его собрания сочинений «За пятьдесят лет», третий том которого составляет «Экспедиция в Сойотию» (1934 г.; об издании 1936 г. см.: Басангова, Бурыкин, Решетов, 2010: Электр. ресурс). Юбилейными являются и такие значимые факты жизни Ф. Я. Кона, участника революционного движения, как арест в 1884 г. по делу международной социал-революционной партии «Пролетариат» («приговорен к 10 годам и 8 месяцам каторжных работ», см.: Кон, 1936: 159) и возвращение из сибирской ссылки на родину, в Варшаву, летом 1904 г. Деятельность Ф. Я. Кона как революционера, участника партийного, государственного и культурного строительства в СССР подробно освещена в многочисленных историографических работах. Вместе с тем, в течение нескольких лет, будучи в ссылке, Феликс Яковлевич занимался научной работой как этнограф и антрополог (в «Автобиографии» отмечается, какое важное значение имел этот период в его жизни, см.: Кон, б. г.: 208). 


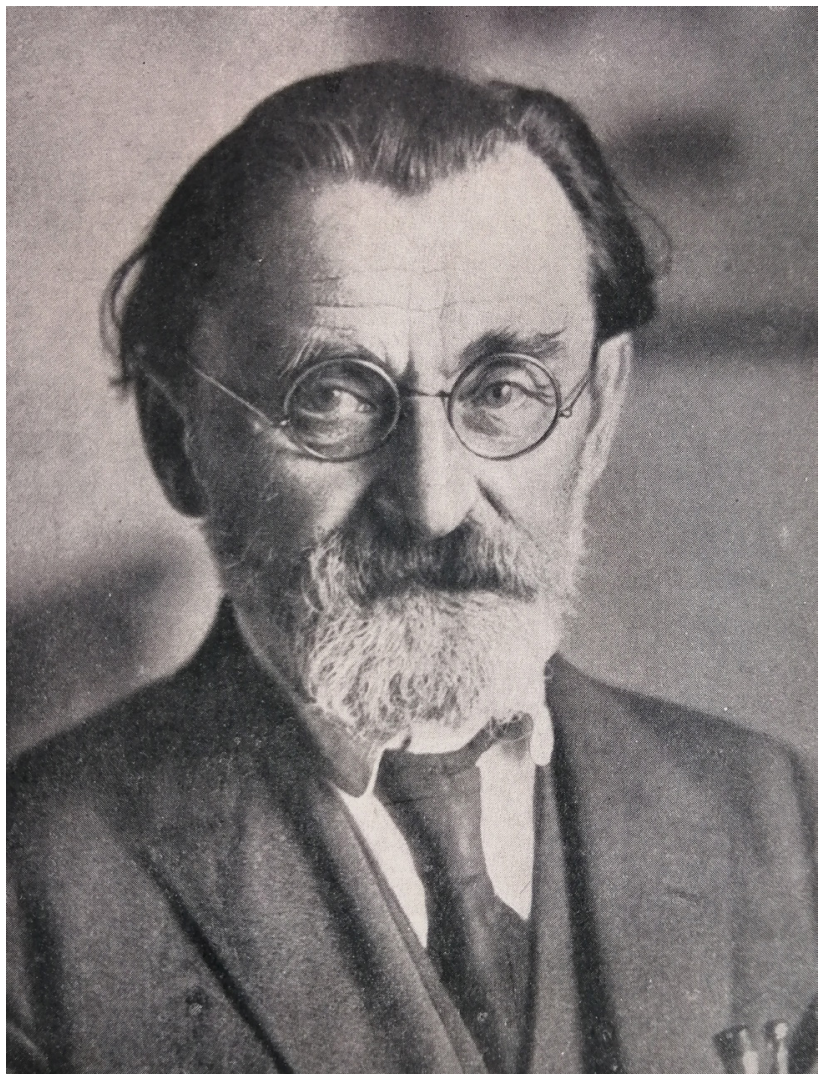

Фото 1. Портрет Ф. Я. Кона - фронтиспис из книги: Кон, Ф. Я. За пятьдесят лет. Т. 3-4. М. : Советский писатель, 1936. 344 c. Photo 1. Portrait of F. Ya. Kon - frontispiece from the book: Kon, F. Ya. In fifty years. Vol. 3-4. Moscow, Sovietsky pisatel, 1936. 344 p.

Особую ценность имеют исследования, относящиеся к этнографии Тувы, причем основные труды Кона по Туве, как подчеркивал Х. М. Сейфулин, написаны в результате его этнографической и антропологической экспедиции, снаряженной Восточным отделом Русского географического общества (Сейфулин, 1964: 354). О серьезности научной работы Ф. Я. Кона по этнографии народов Сибири и Тувы - их истории, материальной и духовной культуре, быту - впервые написал С. И. Вайнштейн (Очерки ... , 1965: 4). В статье «Феликс Яковлевич Кон как этнограф» он собрал основные факты научной деятельности Кона в период сибирской ссылки, вкратце охарактеризовал его опубликованные работы, выявил в архивах новые факты научных занятий ссыльного революционера (Вайнштейн, 1965; см. об этом: Иванов, 1985: 5-6). С. И. Вайнштейн обращает внимание на то, что «наибольшее значение в этнографических исследованиях Кона имела его экспедиция в Туву (в Сойотию, как тогда Тува именовалась), совершенная в 1902-1903 гг. по поручению Северо-Восточного отдела Русского географического общества» (Вайнштейн, 1965: 203). Ф. Я. Кону, по оценке В. И. Дулова, «удалось обследовать все основные районы Тувы, чего до него не сделал ни один исследователь» (Дулов, 1956: 11). На значимость результатов этой экспедиции, «исключительно ценное и богатейшее научное наследие Феликса Яковлевича» для этнографического изучения Тувы указывает М. Х. Маннай-оол (Маннай-оол, 2010: 142, Электр. ресурс). О скрупулезной работе Ф. Я. Кона и важности собранных им материалов пишет К. А. Бичелдей: «В итоге кропотливой работы его экспедиций был собран богатый научный материал - этнографические, антропологические коллекции и несколько сотен фотоснимков» (Бичелдей, 2009: 51).

Научно-экспедиционная деятельность Ф. Я. Кона была высоко оценена почти сразу по завершении работы. На состоявшемся 5 октября 1903 г. годичном заседании Общества любителей естествознания, антропологии и этнографии Д. А. Анучин, президент Общества и председатель Антропологического отдела, представил отзыв, на основании которого Ф. Я. Кону была присуждена «половинная премия и золотая медаль имени А. П. Разцветова ${ }^{1} »$, с оценкой заслуг: «В ряду русских исследователей последнего времени, посвящающих свои труды и время антропологическим и этнографическим исследованиям, одно из видных мест занимает Ф. Я. Кон, который, начиная с лета 1901 г. и по конец лета 1903 г., трудился в земле урянхов, в области верхнего Енисея, и в степях между Саянами и Танну-Ола...» (Присуждение ... , 1904: 14). Об этой награде Ф. Я. Кон узнал в 1904 г., за два месяца до извещения об освобождении из ссылки (Кон, 1934: 289).

Все выявленные научные публикации, касающиеся исследовательской деятельности Ф. Я. Кона, связаны в основном с содержательной частью Засаянской экспедиции; отдельных работ, посвященных ее хронологии, не установлено. Возможно, в какой-то мере это связано с тем, что часть дневника экспедиции, по сведениям самого Ф. Я. Кона, утрачена. «К сожалению, когда я после первого года экспедиции зимою на короткое время ехал для возобновления экспедиционных запасов в Минусинск, я чуть не утонул, попав в санях в полынью, буквально спасенный мною дневник оказался настолько подмоченным, что десятки страниц - неудобочитаемы. Но это еще не все, 一 пишет автор “Экспедиции

${ }^{1}$ Научная премия Императорского общества любителей естествознания, антропологии и этнографии за антропологические исследования. Учреждена в 1889 г. на средства профессора А. П. Разцветова (1822-1902), видного участника Общества. 
в Сойотию”, далее сообщая о потерях части материалов в начале Первой мировой войны. -<...> Когда вспыхнула война, все, что у меня было, осталось во Львове... Многое сохранилось, но 168 первых страниц из дневника пропало безвозвратно» (Кон, 1934: 220).

Целью данной работы является уточнение сведений о Засаянской экспедиции и определение степени репрезентативности дневниковых записей Ф. Я. Кона для топонимических и диалектологических исследований. Источниками для установления хронологии Засаянской экспедиции послужили материалы «Экспедиции в Сойотию» Ф. Я. Кона, его отчеты об экспедиции, отчеты и протоколы заседаний Восточно-Сибирского отдела Императорского Русского географического общества (далее ВСОИРГО), материалы «Русского антропологического журнала», исследования С. И. Вайнштейна, в том числе впервые опубликованные им фрагменты писем и рукописных записей Ф. Я. Кона, и др. Исследование проводилось с опорой на хронологический и компаративный подходы, использовались методы комплексный, сравнительный, хронологический, лингвистический.

\section{Подготовительный этап и первый год экспедиции}

В рассмотренных материалах встречаются разноречивые сведения об экспедиции Ф.Я. Кона, вплоть до казусных. Так, Ревизионная комиссия ВСОИРГО пришла к заключению, что «в 1902 году эта экспедиция не состоялась вопреки указанию Отчета 1902 года», а «осуществилась уже в 1903 году» (Доклад ..., 1904: 5).

Первые документальные сведения об экспедиции встречаются в материалах заседания Распорядительного комитета ВСОИРГО от 27 апреля 1901 г.: «Член комитета А.В.Андрианов сделал предложение командировать в 1902 году Ф. Я. Кона на продолжительное время в Усинский край и Урянхайскую землю, представляющие местность, совершенно неизученную. Поездка эта могла бы дать... богатые результаты. Согласие Ф. Я. Кона уже получено» (Протоколы ..., , 1903а: 64). Комитет вступает в переговоры с Ф. Я. Коном и в июле получает официальное уведомление о его согласии, а также обещание «представить подробную программу, составленную при содействии Г. П. Сафьянова» (Козьмин, 1904: 70). В течение лета Комитет прорабатывал вопрос о получении «разрешения на право разъездов и въезда за русскую границу г. Кону, не имеющему, по своему положению, права свободного передвижения» (там же: 71): обратился с ходатайством к вице-президенту Русского географического общества П. П. Семенову-Тян-Шанскому и иркутскому военному генерал-губернатору. «9-го сентября было получено уведомление о том, что г. Кону разрешено “перейти на жительство в Усинский пограничный округ и производить там разъезды для изучения местного населения с тем, чтобы Кон о каждой отлучке из усинских селений доводил до сведения пограничного начальника”. 7-го октября получил официальное разрешение и г. Кон. Он немедленно принялся за приготовление к экспедиции. В декабре он предоставил подробную программу исследований и план экспедиций», - сообщается в Отчете ВСОИРГО (Козьмин, 1904: 71).

22 ноября положительно решаются вопросы, связанные с материальным обеспечением экспедиции: Ф. Я. Кону разрешают «купить фотографический аппарат и фонограф», кроме того, гарантируют изыскание средств, «если экспедиция продолжится более года» (Протоколы ..., 1903b: 79-80).

7 января 1902 г. на заседании Распорядительного комитета ВСОИРГО было «доложено письмо Ф. Я. Кона, отправляющегося по поручению Отдела в страну сойотов», и программа для собирания этнографических сведений (Протоколы ..., 1903с: 83). «Программа экспедиции в Урянхайскую землю Ф. Я. Кона и Г. П. Сафьянова» опубликована в 1904 г. в составе Отчета ВСОИРГО за 1902 г. (Козьмин, 1904: 72-88). Предполагалось, что в феврале Ф. Я. Кон выедет из Минусинска сначала в Усинский край, затем «на восток и осмотрит долины Бей-хема, Ха-хема, Дод-хема, Хамсары и др.; на восток дойдет до хошуна хасутов около оз. Косогола, а на юг до крайних пределов сойотских кочевников» (Протоколы ... , 1903c: 83).

10 января иркутскому губернатору была направлена просьба о снабжении экспедиции необходимыми документами, ждать которые пришлось довольно долго. Наконец 21 февраля, как указано в Отчете ВСОИРГО, Ф. Я. Кон отправился в путь (Козьмин, 1904: 89). Вместе с тем в его письме от 14 сентября 1902 г., адресованному Д. А. Клеменцу, возглавлявшему Этнографический отдел Русского музея, датой начала экспедиции указывается 22 февраля (Вайнштейн, 1965: 206). 16 марта Ф. Я. Кону приходит предписание с запретом выезда за границу, и 18 марта он, «распустив нанятых для экспедиции людей, вынужден был возвратиться в Минусинск» (Козьмин, 1904: 89). В письме же Д. А. Клеменцу он сообщал, что экспедиция продолжалась по 23 марта (Вайнштейн, 1965: 206). 
В отчете Ревизионной комиссии и объяснении Распорядительного комитета ВСОИРГО отмечалось, что «на пути к осуществлению предприятия» возникли «неожиданные препятствия» (Объяснения ..., 1904: 21). Впоследствии Ф. Я. Кон отвел главу в своей книге объяснению причины, по которой случилась задержка экспедиции. Как ссыльному ему было отказано в выдаче паспорта, необходимого для поездки к сойотам, которые кочевали в монгольских пределах; решить вопрос могли только в столице. «...Я отправил подробную телеграмму в Питер Дмитрию Александровичу Клеменцу, - излагает свою версию начальник Засаянской экспедиции. - Телеграмма вызвала переполох во многих ученых учреждениях. Известия о Засаянской экспедиции уже проникли за границу. Программа предстоявших исследований была напечатана в целом ряде научных изданий» (Кон, 1934: 21). Д. А. Клеменц доложил об этом «музейному начальству, возглавлявшемуся великим князем» (Георгием Михайловичем Романовым. - Г. Н., Н. Г.); «...недели через две получилась бумага, в которой сообщалось, что по соглашению министерства внутренних дел с министром иностранных дел политическому ссыльному Кону разрешается для научных исследований выезд в Монголию, для чего ему должен быть выдан соответствующий паспорт» (Кон, 1934: 21). В это же время активные усилия прилагал Комитет ВСОИРГО, обратившийся «по телеграфу к покровительству и содействию вице-президента Географического общества П. П. Семенова»; по данным Отчета, «желательное разрешение на выезд за границу» Ф. Я. Кон получил лишь в июне (Козьмин, 1904: 89-90).

Ссылаясь на указанное выше письмо Д. А. Клеменца, С. И. Вайнштейн приводит сведения о продолжении Ф. Я. Коном прерванной экспедиции: «6 июня он приехал на Салдам, откуда отправился по p. Улуг-Хему на плоту до Чаа-Холя, а затем на лошадях по р. Хемчику, где находился первый из пунктов стационарного исследования тувинцев» (Вайнштейн, 1965: 206).

В конце сентября Ф. Я. Кон «прислал уже предварительный отчет и программу работ до декабря месяца» (Объяснения ..., 1904: 21): «...до декабря месяца включительно я буду занят исследованием сальджакских, ойнарских и мондинских сойот и дополнительным исследованием русского населения, как в пределах Усинского округа, так и на китайской территории. В конце декабря, по приезде в Минусинск, мною будет представлен следующий отчет» (Козьмин, 1904: 90).

Краткий отчет об экспедиции публикует «Русский антропологический журнал» в последнем номере 1902 г., изданном уже в 1903 г. (Исследования ..., 1902). Письмо Ф. Я. Кона, «приславшего краткое извлечение из собранного материала о сойотах для ознакомления с результатами, достигнутыми в течение 1902 г.», было доложено на заседании Распорядительного комитета СВОИРГО 14 апреля 1903 г. В письме также сообщалось, что в ближайшее время он «отправляется снова в экспедицию и к концу августа или в начале сентября надеется кончить исследования, о результатах коих рассчитывает лично доложить Комитету» (Протоколы ..., , 1903d: 123).

\section{Хронология второго года экспедиции}

Хронология событий 1903 г восстанавливается по 27 и 28 главам «Экспедиции в Сойотию»: «Дорожные встречи и путешествия» И «В Иркутске». Ф. Я. Кон поясняет, что в связи утратой части записей, сделанных во время первого года работы, ему пришлось «поэтому воспроизвести только часть дневника, относящуюся ко второму году экспедиции» (Кон, 1934: 220).

27 марта 1903 г. Ф. Я. Кон покинул Минусинск в составе обоза, поскольку в одиночку ехать по Енисею в это время было опасно. 30 марта добрались до Крутого поворота. Впереди был переезд на Абдырской шивере при впадении в Енисей речки Абдыри и «Кобылья спина», миновав которую остановились на ночлег. 1 апреля в 5 часов утра отправились в сторону Федосовой ямы, благополучно перебрались через нее и, доехав до Камешка, остановились ненадолго, чтобы успеть засветло преодолеть Большой порог, на который пришлось потратить 4 часа. Ночевали на зимовье. «Дальше дорога до с. Усинского не представляла ни опасности, ни интереса, - пишет Ф. Я. Кон. -15 апреля утром я выехал по дороге на Туран, 16-го выехал на Уюк, 17-го я переночевал на берегу Баянгола' ${ }^{1}$, верстах в 25 от Салдама, зимовки Сафьянова...» (Кон, 1934: 224). Отсюда он совершал непродолжительные поездки в различных направлениях.

Первый маршрут продолжался две недели. 24 апреля Ф. Я. Кон вместе с переводчиком отправился к истокам речки Шол ${ }^{2}$. Дорога шла через гору Бом, мимо горы Манган-Элезин (Манган-илезынㄱ). Путь

${ }^{1}$ Баян-Гол.

${ }^{2}$ На бытование в начале XX в. гидронима с данным фонетическим обликом указывает Б. К. Ондар в «Топонимическом словаре

Тувы» (словарные статьи «Шөл» и «өөл») (Ондар, 2007: 67, 520).

${ }^{3}$ Здесь и далее в скобках приводятся топонимы в том фонетическом облике, в каком они были зафиксированы Ф. Я. Коном. 
длиною в 20 верст, из-за поднявшейся песчаной бури, которую пришлось переждать, преодолели лишь к 6 часам утра 25 апреля. Далее дорога пролегала мимо соляного озера Дус-Холь (Тус-куль), озеро Хадын (Кадын) и впадающей в него одноименной речкой. 26 апреля по дороге, проходившей вдоль озера Чедер (Джидер), отправились к сальджакскому огурде - главе одной из девяти административных единиц Сойотии. К вечеру добрались до верховьев реки, остановились на ночлег, чтобы утром осмотреть расположенную здесь кумирню. 27 апреля состоялась встреча с ламой, а когда прибыли в ставку - с огурдой и его семьей. 28 апреля отправились дальше - по дороге вдоль ряда курганов, через гору Кызыл-Даг (Кызыл-таг), к еще одной кумирне. 29 апреля путь продолжился, за горой Даштыг-Кожагар (Таштых-Каджагар) начиналась холмистая степь Балгазын; после спуска к Баян-Гол подъем вверх по течению реки Шуурмак (Шармук, Шормук); ночлег у Дурацкого брода. 30 апреля направились по дороге в сторону улуса нойота - главы всей Сойотии. Путь шел по гористой местности, приходилось преодолевать крутые подъемы и спуски, небольшие речки; до места добрались 2 мая. Путь продолжили 4 мая, через два дня уже ехали по течению реки Шуурмак, затем «повернули к крутой горе КызылМаджалых ${ }^{1}$, торчащей над речкой Маджалых ${ }^{2}$, берега которой тоже были усеяны курганами» (Кон, 1934: 230). 7 мая направились к озеру Чагытай (Джагатай-куль), оттуда - к верховьям Хадына (Кадын). 8 мая, обогнув Кадын и оставив в стороне Дус-Куль, добрались до озера Как-Холь, откуда, нигде не останавливаясь, вернулись в Салдам.

По-видимому, по 20 мая шла стационарная работа на Салдаме. Следующая поездка, о которой сообщает

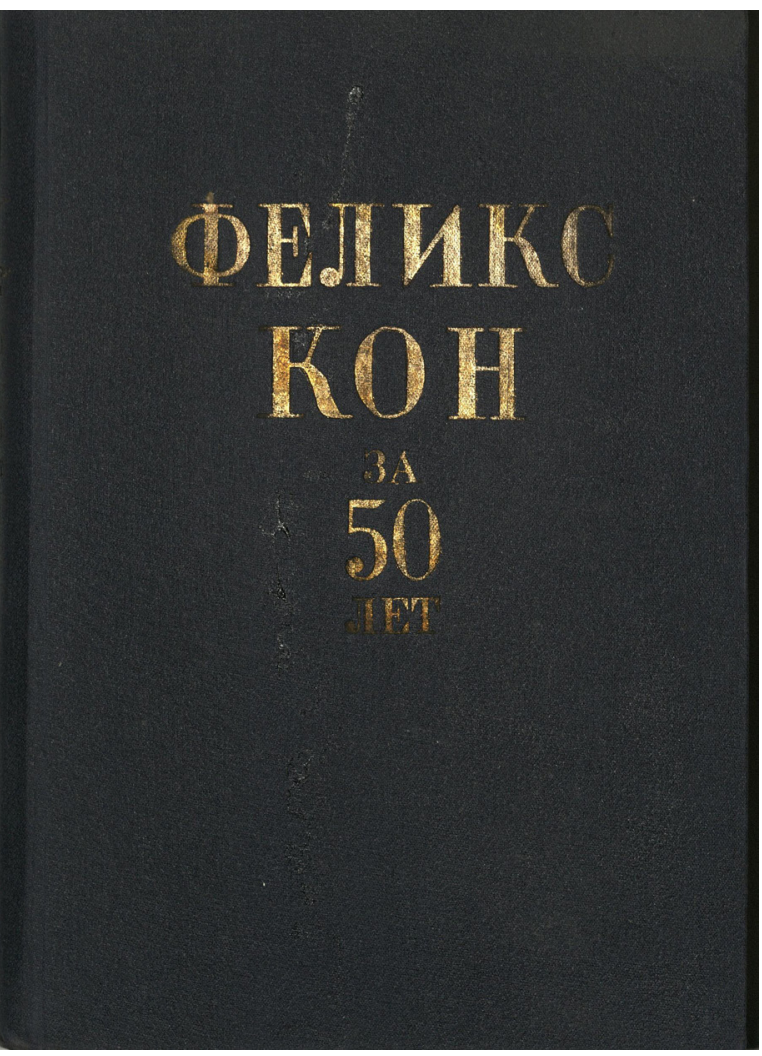

Фото 2. Обложка 3-го тома «Экспедиция в Сойотию» первого издания собрания сочинений Ф. Я. Кона

«За пятьдесят лет» (М.: Издательство Всесоюзного общества политкаторжан и ссыльно-поселенцев, 1934). Предоставлено Костромской областной универсальной научной библиотекой.

Photo 2. Cover of volume 3 (An Expedition to Soyotia) of the first edition of F. Ya. Kon's collected works "In fifty years" (Moscow, Izdatel'stvo Vsesoiuznogo obshchestva politkatorzhan i ssyl'no-pereselentsev, 1934).

Photo courtesy of Kostroma Oblast' Unified Research Library. Ф. Я. Кон, состоялась 21 мая на Межегей (Мичигей), чтобы описать «празднество в связи с молебном о благополучии скота» (там же: 231). Затем по 28 мая продолжалась стационарная работа.

Следующий этап экспедиции длился более двух месяцев. 29 мая Ф. Я. Кон покинул Салдам вместе с торговым караваном, направлявшимся в Малому Енисею. 30 мая началась переправа на правый берег, которая продолжалась в течение следующего дня. 31 выехали на северо-восток, через гору ТосШанчыг (Тос-Шанджик) спустились к реке Теректиг-Хем (Теректых-Кхем), затем к долине Тапсы. На ночлег остановились «на полянке, сплошь изрытой круглыми ямами около метра глубины и полметра в диаметре» - хлебными амбарами сойотов (там же: 233). 1 июня отправились на север, где Ф. Я. Кон впервые увидел берестяные юрты. 2 июня почти весь день занял перевал через хребет Ачалыг-Тайга (Атчилых-тайга), местами покрытый снегом. 3 июня в долине Большой О состоялась встреча с ехавшими на оленях сойотами - охотниками на маралов. На стоянке Ф. Я. Кону довелось увидеть гадание сойотов по лопатке убитой овцы. 4 июня Ф. Я. Кон наблюдает поклонение сойотов шаманской березке и подношение дани (щепок на пнях срубленных деревьев) хозяину лесочка. 9 июня присутствует на камлании шамана, шаманившего по его заказу. 10 июня стал свидетелем присяги сойота. 13 июня «попал на молебен... к одному очень осойоченному монголу» (там же: 242). 16 июня Ф. Я. Кон приобрел у главы местного духовенства карту Сойотии с монгольскими надписями. 17 июня выдвинулись «по дороге к оленным сойотам» (там же: 245), добрались до речки Тоора-Хем (Тора-кхем), вытекающей из озера Тоджа (Тоджи-куль). 18 июня отправились к окруженному горами озеру. На самой высокой

\footnotetext{
${ }^{1}$ Кызыл-Мажалык.

${ }^{2}$ Мажалык.
} 


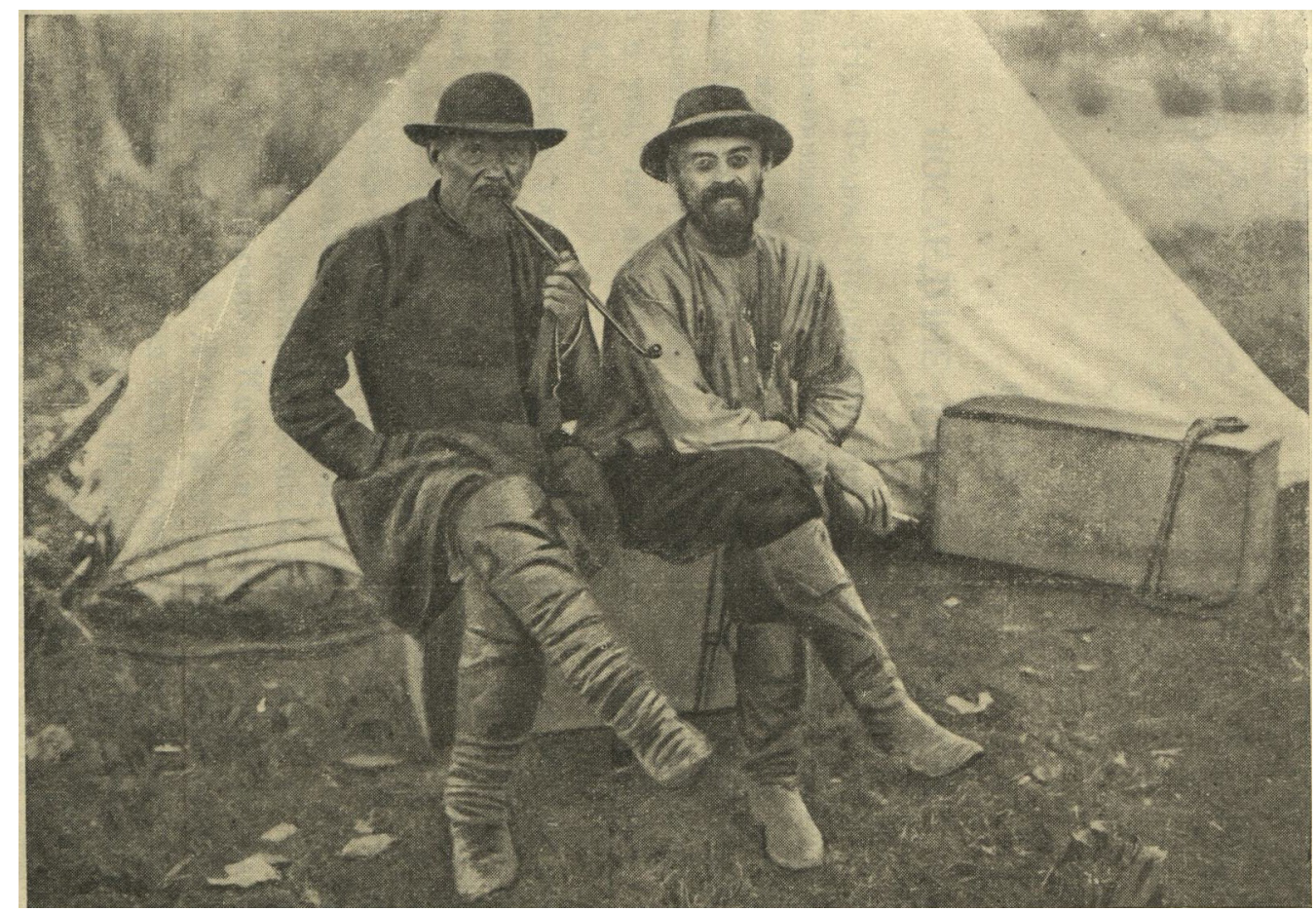

Фото 3. Ф. Я. Кон с переводчиком во время экспедиции (Кон, 1934: 5).

Предоставлено Костромской областной универсальной научной библиотекой.

Photo 3. F. Ya. Kon with his interpreter during the expedition (Kon 1934: 5). Photo courtesy of Kostroma Oblast' Unified Research Library.

горе осмотрели пять необычных оваа - священных мест («алтарь “хозяина места”, духа, владеющего данной местностью, которому делаются... подношения из камней, конских волос и тряпок» (там же: 33)) - с деревянными моделями ружья, мечей, ножей и стрел, деревянными фигурками животных. Возвращение на Тоора-Хем, к месту впадения в Енисей. 19 июня добрались до устья речки Сыстыг-Хем (Систи-кхем). 20 июня переправились на другую сторону Енисея, в улус из берестяных юрт, где жил «почитаемый шаман Хабакшан-хам» (там же: 249). По приглашению шамана Ф. Я. Кон осмотрел юрты его и «одноулусников», обратив внимание на воткнутые в землю перед каждой из них березки, своего рода амулеты, перед которыми совершаются молебствия «о благополучии скота и зверей» (там же: 250). От жителей улуса Ф. Я. Кон узнает о бытовавших у них мерах определения расстояния - «один крик» («расстояние, на котором крик может быть услышан») и «половина крика»; о мере времени, измеряемого «количеством трубок, которые можно выкурить в данный промежуток времени», например, «чтобы закипела чаша с водой» (там же: 250-251). 21 июня в своей палатке принял шамана и жителей улуса, затем вернулся на Дыттыг-Хем (Титтих-Кхем). 22 июня, сплавляясь на плоту по протокам и СыстыгХему, добрались до Енисея, на правом берегу которого «то и дело мелькали избушки пионеров русского переселения» (там же: 253); остановку на ночлег, по-видимому, сделали в Сибинском заселке. 23 июня прошли через Утинский порог. 24 июня к 5 часам утра дошли до Булука, откуда Ф. Я. Кон, оставив спутников, уже через полтора часа добрался до Салдама по суше.

«С 24 июня по 6 июля я приводил в порядок и отправлял коллекции и 6 отправился в последний рейс, по направлению к Косоголу с тем, чтобы оттуда на почтовых добраться до Иркутска», - сообщает он (там же: 256). 6 июля состоялась встреча с землевладельцем Н. М. Черневичем, строившим в Сойотии крупное поместье. 7 июля отправились вверх по берегу Каа-Хем (Хуа-кхем), затем через два перевала спустились в долину Чедер (Джидер). 8 июля, после осмотра курганов, продолжили путь по такому же типу местности, задерживаясь для разговоров со встречными ламами-монголами. 9 июля останавливались в улусах с русскими домами, в которых жили сойоты. 10 июля добрались до реки Бельбей (Бильбей). 11 июля ночевали на берегу речки Сизим (Сизин). 12 июля весь день занял подъем на перевал, на следующий день спустились в долину Улуг-Шивея (Большой Шивей). 14 июня встретили семью сойотского чиновника, промышлявшего молодых маралов, и сойота-скотовода с дочерью. 15 июля еще одна встреча с охотниками. Ф. Я. Кон фиксирует обычай возвращать посуду, в которой преподносилось угощение, с небольшой частью этого угощения - «чтобы посуда (дух, хозяин 
посуды) не обиделась» (там же: 267). 17 июля из улуса, в котором остановились накануне, отправились к сойотам-оленеводам. Ф. Я. Кон интересовался, какое место в их питании занимает оленье молоко. 18 июля расспрашивал о способах его переработки и хранения. Вечером наблюдал камлание шамана. 19 июля двинулись в обратный путь. Во время остановки их посетили хазуты, считавшие себя сойотами. Из-за сильного тумана смогли продолжить путь 21 июля, лишь 23 июля вышли к озеру Тере-Холь (Тери-куль) - конечному пункту маршрута. По приглашению повстречавшегося вблизи кумирни ламы Ф. Я. Кон остановился в его домике. По-видимому, на следующий день осмотрел развалины китайской крепости на одном из островов. «На Тери-куль закончилось возложенное на меня задание. Чем дальше ехали, тем менее встречалось сойотов, тем более они были монголизированы. Начиналась местность, заселенная дархатами», - записывает Ф. Я. Кон (там же: 278). 30 июля доехали до «Горячих вод»лечебных сероводородных источников. 1 августа, двинувшись дальше по земле дархатов, обнаружили улус, в котором жили сойоты, уже позабывшие сойотский язык, но сохранившие элементы культуры предков. «Роскошнее всех виденных» Ф. Я. Коном ранее оказался костюм шамана (там же: 280). 3 августа отправились по дороге к Дархатскому куреню. 4 августа, переехав Малый Енисей, добрались до дархатской кумирни. Сделав визит главе лам, Ф. Я. Кон «помчался назад в Сибирь, и как только добрался до первой русской почтовой станции, на почтовых помчался в Иркутск» (там же: 281).

В Иркутске Ф. Я. Кон провел несколько дней. 20 августа состоялся его доклад на закрытом заседании Комитета Географического общества. Текст протокола заседания, опубликованный в «Известиях ВСОИРГО» (Протоколы ..., 1903d: 125-126), приведен в «Экспедиции в Сойотию» (Кон, 1934: 283-285).

«За добросовестно выполненный труд и за интересное сообщение» Ф.Я. Кону была принесена «глубочайшая благодарность» (там же: 285). К вопросу о Засаянской экспедиции Распорядительный комитет ВСОИРГО возвращается спустя два месяца, 24 октября, в связи с представленным Ф. Я. Коном списком лиц, «которые оказывали содействие и разные услуги во время экспедиции»: «Постановлено: Послать этим лицам письма с выражением благодарности от Отдела» (Протоколы ..., 1903d: 130).

\section{Заключение}

Хронология экспедиции позволяет уточнить ход исследований, проведенных Ф. Я. Коном. Собранные материалы в основном этнографического характера. Вместе с тем они представляют несомненную ценность для лингвистов, в первую очередь топонимистов и диалектологов. Так, в «Экспедиции в Сойотию» встречаются имена собственные географических объектов - населенных пунктов, рек и речек, озер, гор, перевалов и т. д., в том числе русские: Сибинский заселок, Кордон, Абдырская шивера, Большой порог, Крутой поворот, Кобылья спина, Федосова яма, Камешек и др. Соотнесение с современным топонимиконом края позволит выявить несохранившиеся именования, а выстраиваемый по хронологии маршрут экспедиции - уточнить их географию. При этом, однако, надо учитывать то, что многие топонимы, бытовавшие на территории Тувы в начале XX столетия, фиксировались Ф. Я. Коном с искаженным фонетическим обликом: исследователь записывал их так, как ему слышалось. Материалы экспедиции интересны и для филологов, изучающих русские диалекты: в записях Ф. Я. Кона встречаются областные слова, употреблявшиеся в речи русских переселенцев; в основном это географические апеллятивы - «балаган», «забереги», «заимка», «заселок», «кочкарник», «материк», «наледь», «нанос», «тихое плесо» и др., но обнаруживаются также термины других лексических групп, например, лексика семейных отношений - «бросовка», «чехунда», названия болезней скота - «веснянка», «мыт», «сжатие санок», «запал», «ноготь» и др.

Можно полагать, что в дневнике Засаянской экспедиции, обнаруженном более полувека назад, но не опубликованном до настоящего времени, имеются и другие, не попавшие в поле зрения филологов, лексические материалы, которые вместе с уже выявленными станут предметом научного исследования.

\section{СПИСОК ЛИТЕРАТУРЫ}

Басангова, Т. Г., Бурыкин, А. А., Решетов, А. М. (2010) Неизвестное издание Ф. Я. Кона [Электронный ресурс] // Новые исследования Тувы. № 2. С. 143-156. URL: https://nit.tuva.asia/nit/article/view/535 (дата обращения: 14.05.2019).

Бичелдей, К. А. (2009) «Золотой век» тувиноведения и перспективы развития гуманитарных исследований в Туве // Проблемы востоковедения. № 2 (44). С. 48-55. 
Вайнштейн,С.И.(1965) Феликс Яковлевич Кон как этнограф// Очерки по истории русской этнографии, фольклористики и антропологии. Вып. 3. / Труды Института этнографии им. Н. Н. Миклухо-Маклая. Новая серия. Т. 91. М. : Наука. 222 с. С. 196-220.

Доклад комиссии, избранной для ревизии деятельности Восточно-Сибирского Отдела за 1901-1903 г. (1904) // Известия Восточно-Сибирского отдела Императорского Русского географического общества. Т. 35, № 3. Приложение. С. 1-14.

Дулов, В. И. (1956) Социально-экономическая история Тувы XIX - начала XX в. М. : Издательство Академии наук СССР. 608 с.

Иванов, В. Н. (1985) Народы Сибири в трудах Ф. Я. Кона. Новосибирск : Наука, Сибирское отделение. 172 с.

Исследования Ф. Я. Кона в земле урянхов (1902) // Русский антропологический журнал. № 4. C. 116-120.

Козьмин, Н. Н. (1904) Отчет Восточно-Сибирского Отдела Императорского Русского Географического Общества за 1902 год // Известия Восточно-Сибирского отдела Императорского Русского географического общества. Т. 35, № 1. С. 53-92.

Кон, Ф. Я. (б. г.) Автобиография // Энциклопедический словарь Гранат. Т. 41, ч. 1. 7-е изд. М. : Русский библиографический институт Гранат. Стб. 201-2011.

Кон, Ф. Я. (1934) Экспедиция в Сойотию // За пятьдесят лет : в 3 т. М. : Издательство Всесоюзного общества политкаторжан и ссыльно-переселенцев. Т. 3. 296 с.

Кон, Ф. Я. (1936) За пятьдесят лет. 2-е изд. М. : Советский писатель. Т. 3-4. 344 с.

Маннай-оол, М. Х. (2010) Вклад Ф. Я. Кона в этнографическое изучение Тувы [Электронный ресурс] // Новые исследования Тувы. № 2. С. 135-142. URL: https://nit.tuva.asia/nit/article/view/534 (дата обращения: 14.05.2019).

Объяснения Распорядительного комитета В.-Сиб. Отдела И.Р.Г. Общества на замечания Ревизионной комиссии по ревизии 1901-1903 гг. // Известия Восточно-Сибирского отдела Императорского Русского географического общества. Т. 35, № 3. Приложение. С. 14-29.

Ондар, Б. К. (2007) Топонимический словарь Тувы. 2-е изд., перераб. Кызыл : Тувинское книжное издательство. 551 с.

Очерки по истории русской этнографии, фольклористики и антропологии. (1965) Вып. 3. / Труды Института этнографии им. Н. Н. Миклухо-Маклая. Новая серия. Т. 91. М. : Наука. 222 с.

Присуждение Ф. Я. Кону половинной премии и золотой медали имени А. П. Разцветова (1903) // Русский антропологический журнал. № 3/4. Известия и заметки. С. 14-15.

Протоколы заседаний Распорядительного комитета Восточно-Сибирского Отдела И. Р. Г. О. 30-го января 1901 года (1903a) // Известия Восточно-Сибирского отдела Императорского Русского географического общества. Т. 34, № 2. С. 47-77.

Протоколы заседаний Распорядительного комитета. 22-го ноября 1901 года (1903b) // Известия Восточно-Сибирского отдела Императорского Русского географического общества. Т. 34, № 2. С. 79 -81.

Протоколы заседаний Распорядительного комитета. 7-го января 1902 года (1903c) // Известия Восточно-Сибирского отдела Императорского Русского географического общества. Т. 34, № 2. С. 83-88.

Протоколы заседаний Распорядительного комитета. 14-го апреля 1903 года (1903d) // Известия Восточно-Сибирского отдела Императорского Русского географического общества. Т. 34, № 2. С. 120-126.

Протоколы заседаний Распорядительного комитета. 24-го октября 1903 года (1903e) // Известия Восточно-Сибирского отдела Императорского Русского географического общества. Т. 34, № 2. С. 127-130.

Сейфулин, Х. М. (1964) Феликс Яковлевич Кон (К 100-летию со дня рождения) // Ученые записки (ТНИИЯЛИ). Вып. 11. 20 лет Советской Тувы. Кызыл : Тувинское книжное издательство. С. 350-358.

Дата поступления: 01.08.2019 2.

\section{REFERENCES}

Basangova, T. G., Burykin, A. A. and Reshetov, A. M. (2010) Neizvestnoe izdanie F. Ia. Kona [Unveiled publication of F.Y. Kohn]. The New Research of Tuva, no. 2 [online] Available at: URL: https://nit.tuva.asia/nit/ article/view/535 (access date: 14.05.2019). (In Russ.). 
Bicheldei, K. A. (2009) «Zolotoi vek» tuvinovedeniia i perspektivy razvitiia gumanitarnykh issledovanii v Tuve [The Golden age of Tuva studies and prospects for the development of humanities research in Tuva]. The Problems of Oriental Studies, no. 2 (44), pp. 48-55. (In Russ.).

Vainshtein, S. I. (1965) Feliks Iakovlevich Kon kak etnograf [Felix Yakovlevich Kon as an ethnographer]. In: Ocherki po istorii russkoi etnografii, fol'kloristiki i antropologii [Essays on the history of Russian ethnography, folklore and anthropology], issue 3 / Trudy Instituta etnografii im. N. N. Miklukho-Maklaia. Novaia seriia. Moscow, Nauka Publ.Vol. 91. Pp. 196-220. (In Russ.).

Doklad komissii, izbrannoi dlia revizii deiatel'nosti Vostochno-Sibirskogo Otdela za 1901-1903 g. (1904) [Report of the Committee chosen to audit the activities of the Eastern-Siberian Department for the years 1901-1903]. Izvestiia Vostochno-Sibirskogo otdela Imperatorskogo Russkogo geograficheskogo obshchestva, vol. 35, no. 3, Prilozhenie, pp. 1-14. (In Russ.).

Dulov, V. I. (1956) Sotsial'no-ekonomicheskaia istoriia Tuvy. XIX - nachalo XX v. [The socio-economic history of Tuva: XIX - early XX centuries]. Moscow, Akademia nauk SSSR Publ. 608 p. (In Russ.).

Ivanov, V. N. (1985) Narody Sibiri $v$ trudakh F. Ia. Kona [Peoples of Siberia in the writings of F. Ya. Kon]. Novosibirsk, Nauka Publ., Sibirskoe otdelenie. 172 p. (In Russ.).

Issledovaniia F. Ya. Kona v zemle uriankhov (1902) [F. Ya. Kon's research in the land of the Uryankh]. Russkii Antropologicheskii zhurnal, no. 4, pp. 116-120. (In Russ.).

Koz'min, N. N. (1904) Otchet Vostochno-Sibirskogo Otdela Imperatorskogo Russkogo Geograficheskogo Obshchestva za 1902 god [The Report of the East Siberian Department of the Imperial Russian Geographical Society for the year 1902]. Izvestiia Vostochno-Sibirskogo otdela Imperatorskogo Russkogo geograficheskogo obshchestva, vol. 35, no. 1, pp. 53-92. (In Russ.).

Kon, F. Ya. (s. a.) Avtobiografiia [Autobiography]. In: Entsiklopedicheskii slovar' Granat. Vol. 41, part 1. 7nd ed. Moscow, Russkii bibliograficheskii institut Granat Publ. Stb. 201-2011. (In Russ.).

Kon, F. Ya. (1934) Ekspeditsiia v Soiotiiu [An Expedition to Soyotia]. Za piat'desiat let [In fifty years]: in 3 vols. Moscow, Izdatel'stvo Vsesoiuznogo obshchestva politkatorzhan i ssyl'no-pereselentsev. Vol. 3. 296 p. (In Russ.).

Kon, F. Ya. (1936) Za piat'desiat let [In fifty years]. $2^{\text {nd }}$ ed. Vol. 3-4. Moscow, Sovetskii Pisatel' Publ. 344 p. (In Russ.).

Mannai-ool, M. Kh. (2010) Vklad F. Ia. Kona v etnograficheskoe izuchenie Tuvy [F.Y. Kohn's contribution to the ethnographic research of Tuva]. The New Research of Tuva, no. 2 [online] Available at: https://nit.tuva.asia/ nit/article/view/534 (access date: 14.05.2019) (In Russ.).

Ob'iasneniia Rasporiaditel'nogo komiteta V.-Sib. Otdela I. R. G. Obshchestva na zamechaniia Revizionnoi komissii po revizii 1901-1903 gg. [A Response of the Steering Committee of East Siberian Department of I[mperial]. R[ussian]. G[eographical]. Society to the comments of the Revision Commission for Audit, 1901-1903]. Izvestiia Vostochno-Sibirskogo otdela Imperatorskogo Russkogo geograficheskogo obshchestva, vol. 35, no. 3, app, pp. 14-29. (In Russ.).

Ondar, B. K. (2007) Toponimicheskii slovar' Tuvy [A toponymic dictionary of Tuva]. $2^{\text {nd }}$ ed. Kyzyl, Tuvan book publisher. 550 p. (In Russ.).

Ocherki po istorii russkoi etnografii, fol'kloristiki i antropologii [Essays on the history of Russian ethnography, folklore and anthropology] (1965) Vol. 3. Moscow, Nauka Publ. 222 p. / Trudy Instituta etnografii im. N. N. Miklukho-Maklaia. Novaia seriia. Vol. 91. (In Russ.).

Prisuzhdenie F. Ya. Konu polovinnoi premii i zolotoi medali imeni A. P. Raztsvetova [F. Ya. Kon awarded the A. P. Razsvetov Half Prize and Gold Medal] (1903). Russkii antropologicheskii zhurnal, no. 3/4. Izvestiya i zametki. Pp. 14-15. (In Russ.).

Protokoly zasedanii Rasporiaditel'nogo komiteta Vostochno-Sibirskogo Otdela I. R. G. O. 30-go yanvarya 1901 goda [Minutes of the meetings of the Steering Committee of the East Siberian Division of I[mperial]. R[ussian]. G[eographical]. Society. January 30, 1901] (1903a). Izvestiia Vostochno-Sibirskogo otdela Imperatorskogo Russkogo geograficheskogo obshchestva, vol. 34, no. 2, pp. 47-77. (In Russ.).

Protokoly zasedanii Rasporiaditel'nogo komiteta. 22-go noyabrya 1901 goda [Minutes of the meetings of the Steering Committee. November 22, 1901] (1903b). Izvestiia Vostochno-Sibirskogo otdela Imperatorskogo Russkogo geograficheskogo obshchestva, vol. 34, no. 2, pp. 79-81. (In Russ.). 
Protokoly zasedanii Rasporiaditel'nogo komiteta. 7-go yanvarya 1902 goda [Minutes of the meetings of the Steering Committee. January 7, 1902] (1903c). Izvestiia Vostochno-Sibirskogo otdela Imperatorskogo Russkogo geograficheskogo obshchestva, vol. 34, no. 2, pp. 83-88. (In Russ.).

Protokoly zasedanii Rasporiaditel'nogo komiteta. 14-go aprelya 1903 goda [Minutes of the meetings of the Steering Committee. April 14, 1903] (1903d). Izvestiia Vostochno-Sibirskogo otdela Imperatorskogo Russkogo geograficheskogo obshchestva, vol. 34, no. 2, pp. 120-126. (In Russ.).

Protokoly zasedanii Rasporiaditel'nogo komiteta. 24-go oktyabrya 1903 goda [Minutes of the meetings of the Steering Committee. October 24, 1903] (1903e). Izvestiia Vostochno-Sibirskogo otdela Imperatorskogo Russkogo geograficheskogo obshchestva, vol. 34, no. 2, pp. 127-130. (In Russ.).

Seifulin, Kh. M. (1964) Feliks Iakovlevich Kon (K 100-letiiu so dnia rozhdeniia) [Felix Yakovlevich Kon (On the occasion of the 100 th birthday)]. Uchenye zapiski (TNIIYaLI), vol. 11. 20 let Sovetskoi Tuvy. Kyzyl, Tuvan book publisher. Pp. 350-358. (In Russ.).

Submission date: 01.08.2019. 